\title{
From Convergence to Divergence: The Compatibility of Turkish and EU Foreign Policy
}

\section{Zerrin Torun}

\subsection{INTRODUCTION ${ }^{1}$}

Turkey's potential contributions to the European Union's (EU) foreign policy used to be considered as one of the reasons for offering EU membership to Turkey. For instance, writing in 2004, Emerson and Tocci (2004: 33) argued that if the EU truly aspires to play a stabilizing, pacifying and modernizing role in its neighborhood beyond mere token actions, then the incorporation of Turkey into the common external policy offers the prospect of real advantages'. However, in order for Turkey to bring added value to the EU's foreign policy, the foreign policies of the two sides have to be compatible. This chapter analyzes Turkish foreign policy between 1959 and 2020 and its compatibility with EU foreign policy in this period. The notion of compatibility refers to the

${ }^{1}$ I thank the editors for their suggestions on how to improve this chapter.

\footnotetext{
Z. Torun $(\bowtie)$

Department of International Relations, Middle East Technical University (METU), Ankara, Turkey e-mail: zerrin@metu.edu.tr

(C) The Author(s) 2021 
quality of mutual tolerance, consistency, and congruity (Oxford English Dictionary, 2020). In the context of foreign policy, as it is used here, it refers to the degree of harmonization or convergence between Turkey's and the EU's foreign policies.

In Turkey's EU accession negotiations, Chapter 31, titled 'foreign, security, and defense policy', requires full alignment of Turkey's foreign policy with that of the EU. Analyzing the compatibility is thus not only an academic exercise, but also a political concern. Greater compatibility of the two foreign policies can, thus, also be seen as an indicator of how close Turkey is to the fulfilment of relevant EU membership criteria. Beyond the membership question, a greater compatibility also implies more chances for cooperation and a higher probability for collective initiatives in foreign affairs.

The study of compatibility between the EU's and Turkey's foreign policies has drawn attention from a limited number of scholars in comparison with the study of Turkish foreign policy in general. The vast majority of studies dealing with the period before the outbreak of Arab uprisings in 2010 and 2011 argue that Turkey's full membership in the EU would strengthen the EU's foreign policy, especially toward its neighbors (Ünal Eriş, 2007; Eralp, 2010; Üstün, 2010). Analyses of the compatibility of Turkey's foreign policy with that of the EU in the period after the Arab Spring are rare. Two examples of work assessing potential cooperation between the parties in foreign policy toward the Middle East come to conflicting conclusions. One view is that cooperation between the EU and Turkey over Arab countries would be a non-zero-sum game in which the two sides would complement each other's deficiencies (Dinçer \& Kutlay, 2013: 2). The other view argues that Turkey's increasingly independent and sectarian stance, coupled with its assertive tone, makes it hard for Turkey to complement EU initiatives (Evin \& Hatipoğlu, 2014: 187). This study falls within the latter camp, arguing that in the period after the Arab uprisings, the foreign policies of the EU and Turkey have steadily diverged.

The analysis follows Christopher Hill's definition of foreign policy as 'the sum of official external relations conducted by an independent actor (usually but not exclusively a state) in international relations' (Hill, 2016: 4). This definition potentially includes all types of external actions, including those related to economic relations, but the chapter confines its analysis to the issues covered by the EU's Common Foreign and Security Policy (CFSP). By doing so it focuses on the EU's external political 
and security relations, excluding member states' individual positions, policies, or declarations. The chapter also excludes foreign policies that the EU and Turkey pursue in multilateral fora, such as in the framework of the United Nations (UN) or the G20. In institutional terms, the analysis concentrates on key actors of EU foreign and security policy, including the High Representative of the Union for Foreign Affairs and Security Policy and vice president of the European Commission (EC), the European Council, the Council of the EU, and the European External Action Service (EEAS). On the Turkish side, the president, prime minister (until 2018, when the office of the premiership was abolished), and the Ministry of Foreign Affairs are the primary handlers of foreign and security issues.

The chapter starts by setting forth the points of convergence and divergence between Turkish and European foreign policies until 1998. The following section analyzes the compatibility of Turkish and EU foreign policies between 1999 and 2002, and continues with an examination of the foreign policy during the Justice and Development Party (Adalet ve Kalkınma Partisi, AKP) governments, in power since 2002. The period between 2003 and 2010 is distinguished from the period after 2010 (the period after the Arab uprisings), as there is a higher degree of compatibility with the EU's foreign policy before 2011. The conclusion discusses the prospects for future cooperation between Turkey and the EU by taking into account the latest regional and international developments.

\subsection{Starting Points of Convergence AND Divergence Within The Western Alliance: I959-I998}

The founders of the Turkish Republic in the 1920s and 1930s sought to create a Turkey aligned with the West, in particular Europe, as they perceived the West as the most modern, advanced civilization of the time. With the Cold War and the disclosure of Soviet intentions to control Turkish territory, especially with regard to the Bosporus and Dardanelles, Turkey's alignment with the West was even perceived as a necessity. Turkey became a member of the North Atlantic Treaty Organization (NATO) in 1952 and sought membership in other Western international organizations as part of its security strategy. Turkey's application for an association agreement with the European Economic Community (EEC) in July 1959 was also motivated by security concerns, although the goal of 
balancing Greece, which applied for association in June 1959, influenced the timing of the application (see also Turhan \& Reiners, Chapter 1). Confrontational relations between Greece and Turkey made it necessary for Turkey to seek membership of international organizations of which Greece was also a member in order not to be targeted by the international organization in question.

Turkey acted as a staunch ally of the West during much of the Cold War, which often put it at odds with its Middle Eastern neighbors. It was part of the efforts to establish the Baghdad Pact (1955) as a security organization for the Middle East, which did not receive much favor from Middle Eastern countries. Turkey voted against Algerian independence at the UN between 1954 and 1961 in line with Western countries. Turkey's recognition of Israel in 1949 was another step that distanced it from the Middle East at the time.

When the Greek military junta deposed then Cypriot President Archbishop Makarios to establish the union of Cyprus with Greece, Turkey militarily intervened in Cyprus in order to protect Turkish Cypriots in 1974 (Hale, 2000: 155). As the negotiations between the parties did not lead to a settlement, Turkish forces have remained in Northern Cyprus until today. The island has been effectively divided into two separate entities. After the intervention, the member states of the European Communities issued a communiqué reaffirming their 'support for the independence and territorial integrity of Cyprus and their opposition to any intervention or interference tending to put it in question' (European Political Cooperation, 1974). Since then, the EU has continued to express support for territorial integrity and the independence of Cyprus (see, e.g., European Council, 1988).

Despite this divergence, a series of developments showed the compatibility of the foreign policies of Turkey and the EEC. Both the EEC and Turkey condemned the Soviet Union's invasion in Afghanistan in 1979 (European Political Cooperation, 1980; Tellal, 2008: 781) and the Israeli military campaign in Lebanon in 1982 (European Political Cooperation, 1982; Fırat \& Kürkçüoğlu, 2008: 128). Also, both actors supported the settlement of the Israeli-Palestinian conflict on the basis of the UN Security Council Resolutions 242 (1967) and 338 (1973), which called for Israel's withdrawal from territories occupied in 1967 and for negotiations between the parties to establish a just and durable peace (see European Political Cooperation, 1973; Republic of Turkey Ministry of Foreign Affairs, 2020). Another area where Turkey and the EU shared a 
common understanding was their interpretation of the Bosnian War in the early 1990s. Both saw Serbia and Bosnian Serbs as responsible for much of the violence and the Muslim population of Bosnia-Herzegovina as the principal victims of aggression (European Council, 1992: 101), although Turkey went further in suggesting that harsher precautions should be taken against the Serbs (Uzgel, 2008: 493).

Turkey's foreign policy positions were generally compatible with those of the EEC (EU after, 1992) until 1998. Turkey's foreign policy during the Cold War and its immediate aftermath was primarily shaped by the goal of being recognized as part of the Western community of states and by NATO's preferences, membership of which it shared with most of the EEC/EU member states (Sözen, 2010: 116). Exceptional divergences between the foreign policies of Turkey and the EEC/EU included Turkey's position on the Cyprus problem, and its territorial disputes with Greece, which is against the EU principle of 'good neighborly relations' (European Commission, 1998: 52). Relations with Middle Eastern countries, except Israel, were limited. To illustrate, in 1997, then Turkish President Süleyman Demirel was forced to depart from an Organization of Islamic Conference meeting as a result of intense criticism over Turkey's relations with Israel (Milliyet, 1997). During this period, Turkey-Africa and Turkey-Central Asia relations were almost nonexistent. Toward the end of the 1990s, Turkey's foreign policy agenda started to expand in terms of geography, number of issues, and foreign policy tools (Sözen, 2010: 116).

\subsection{Turkey's Regional ACTIVISM À LA EU: 1999-2002}

After Turkey was granted candidate status at the Helsinki European Council in 1999, and until AKP came to power in 2002, a coalition government formed by the Democratic Left Party (DSP), Motherland Party (ANAP), and Nationalist Action Party (MHP) shaped Turkey's foreign policy. During this term, İsmail Cem was the minister of foreign affairs, having held this post in previous coalition governments since June 1997. Cem is said to have laid the foundation for an active foreign policy in Turkey's neighborhood (Kirişci, 2018: 55). In the words of Kirişci (2018: 55), 'his initiatives for regional engagement can also be regarded as a precursor to Davutoğlu's more ambitious regional integration projects', which could be observed in particular in the subsequent 
period, between 2003 and 2010. Greek-Turkish rapprochement can be regarded as Cem's enduring legacy. After massive earthquakes in both countries in 1999, Cem and Greek foreign minister George Papandreou reenergized the relations between the two countries. The cordial relationship even led to Greece waiving its veto over Turkey's EU membership candidacy.

Turkey's new regional activism also found expression in the Caucasus Stability Pact, open to all member states of the Organization for Security and Cooperation in Europe, which was proposed by President Süleyman Demirel in 2000 with the aim of stabilizing the Caucasus. Cem revised this proposal in February 2001 and argued in favor of a $3+3+2$ framework, which would include not only Armenia, Georgia, Azerbaijan, and Turkey but also Iran, Russia, the EU, and the United States. Although conflicts within and between countries in the region prevented the Stability Pact from materializing, including the EU in the plan demonstrates Turkey's aspiration for joint measures with the EU in the region (Winrow, 2007: 128).

As documented in the Commission progress reports on Turkey in 1998 and 1999, Turkey had not asked to be associated with the EU's CFSP positions during this period (European Commission, 1998: 51; 1999: 41). The situation changed after the Helsinki Summit in 1999, when the EU granted candidacy status to Turkey and thus made the membership prospect credible. The decision motivated Turkey to move closer to EU standards and foreign policy positions. The progress report of 2000 pointed out that Turkey 'regularly aligned its positions with those of the Union and when invited to do so has associated itself with the Union's joint actions and common positions' (European Commission, 2000: 67). Turkey continued the practice of alignment with EU statements and declarations and associated itself with the Union's joint actions and common positions in 2001 and 2002 (European Commission, 2001: 89; 2002: 127). However, Turkey's pursuit of connecting its foreign policy initiatives with the EU also went beyond the CFSP. In February 2002, Turkey organized a forum on the harmony of civilizations that brought together the EU and the Organization of Islamic Conference in Istanbul. The EC's progress report of 2002 noted that the forum was important in 'promoting dialogue and mutual understanding between EU countries and Muslim countries across the world' (European Commission, 2002: 128). 
As Hatipoğlu and Palmer (2016: 234) argue, the end of the Cold War enhanced Turkey's willingness to become more active in its foreign policy; however, at the same time, Turkey's abilities were still limited. Turkey did not always achieve positive results from its regional initiatives, as can be seen in its proposal for a Caucasus Stability Pact. Nevertheless, the period from 1999 to 2002 marked the beginning of Turkey's regional activism and underpinned its clear efforts to align its foreign policy with that of the EU.

\subsection{TURKey AdOPTS THE EU's SOFT POWER APPROACH: 2003-20IO}

The AKP government came to power after the November 2002 parliamentary elections. Its foreign policy was guided by the 'strategic depth' doctrine of Ahmet Davutoğlu, who served as first foreign policy advisor of then Prime Minister Recep Tayyip Erdoğan, then foreign minister (20092014), and lastly prime minister (2014-2016). For Davutoğlu (2001: 552 ), the historical and geographic complexity of countries provide them with important assets for a long lasting and strategic approach to foreign policy making. For him, Turkey's historical and geographic 'depth' places Turkey at the center of its neighboring regions and offers a potentially extensive influence which should be utilized (Altunışık \& Çuhadar, 2010: 376).

A major foreign policy challenge faced by the AKP government throughout this period was the Cyprus conflict. In 2004, when all Cypriots were offered a vote on implementing the 'Annan Plan' as a solution to the Cyprus conflict, the AKP government adopted a policy in favor of the plan with a view to harmonizing its approach with the EU. This was a major change from Turkey's previous understanding of the Cyprus dispute, which can be summarized in the slogan 'no solution is the solution' of the previous military-bureaucratic establishments (Sözen, 2013: 116). Approximately $65 \%$ of Turkish Cypriots approved the plan, whereas $76 \%$ of Greek Cypriots rejected it. As a result, Cyprus became a member of the EU as a divided island, leaving the EU and Turkey with a complex unresolved challenge, which had developed in the realm of foreign policy but was then turned into a question of bilateral EU-Turkey relations.

Building on Davutoğlu's 'zero problems with neighbors' approach, Turkish policymakers spoke of Turkey's ambition of becoming a global power and of instituting regional order. In this context, Turkey's policy 
toward its neighborhood aligned with the EU's 'soft power' approach and employed resources such as 'cultural attraction, ideology, and international institutions' (Nye, 1990: 167). ${ }^{2}$ In 2003, the EU defined Turkey as 'an important actor in promoting stability and security in its region (Balkans, Caucasus, Mediterranean, and the Middle East)' and stated that it 'has taken a number of initiatives within this role' (European Commission, 2003: 124). In 2004, it welcomed Turkey's efforts 'to improve and deepen its relations with the neighboring countries' (European Commission, 2004: 155). Turkey facilitated talks between Afghanistan and Pakistan in 2007 and also took on a facilitator role in regional conflicts between Syria and Israel in 2008 and between Serbia and Bosnia-Herzegovina in 2009.

At the same time, Turkey tried to improve its relations not only with its immediate neighbors but also in other regions. A strategic dialogue mechanism was established with the Gulf Cooperation Council in 2008, and a strategic partnership was initiated between Turkey and the African Union in 2008. In its relations with neighbors, Turkey followed the EU model of engaging in functional cooperation in order to establish peaceful relations. Between 2008 and 2010, it created High Level Strategic Cooperation Councils, not only with Iraq, Syria, and Greece but also with Russia, in which cabinets worked on a variety of issues such as healthcare, culture, trade, transportation, and energy. The coexistence of democracy, secularism, economic success, and balanced foreign policy made Turkey a role model in the Middle East (Torun, 2016). In contrast with the 1990s, Turkey was well received in the Organization of Islamic Conference, and in 2004, the Turkish academic and politician Ekmeleddin İhsanoğlu was elected as the secretary general of the organization and remained in office for almost ten years. These examples illustrate how Turkey tried to embed itself in bi- and multilateral partnerships and how it increased its cultural and political attraction and visibility with methods similar to those employed by the EU.

However, this period also saw actions contradicting EU positions on certain foreign policy issues. For instance, Turkey recognized the result of the Palestinian elections in 2006, which gave Hamas the majority in the

2 'Soft power' is typically contrasted with 'hard power', which refers to coercion and use of force. For more information on the concept see Nye (1990). For a discussion of Turkey's soft power approach in the foreign policy and migration nexus, see also Kaya, Chapter 14. 
parliament, and Hamas leader Khaled Mashal was welcomed in Turkey after the elections. The United States, Israel, and the EU, in contrast, demanded that Hamas disarm and recognize Israel as a condition for the acceptance of the election results (Daily Sabah, 2017). However, the EU's response to Mashal's visit to Turkey was mild, emphasizing the potential for a positive outcome from the visit, with then EU High Representative Javier Solana suggesting that the visit could help reinforce the conditions set by the Quartet (the EU, the UN, the US, and Russia) for Hamas to renounce violence and recognize Israel (Krieger, 2006). Another incident that indicated divergence from the EU was Brazil's and Turkey's brokering of a deal with Iran on its nuclear capabilities in 2010. Although the office of then EU High Representative Catherine Ashton regarded the deal as a move in the right direction, it stated that 'it [did] not answer all of the concerns raised over Iran's nuclear program' (Blua, 2010). The UN Security Council did not approve the deal either and increased sanctions against Iran. As a member of the UN Security Council at that time Turkey voted against these sanctions.

Likewise diverging from the EU, Turkish-Israeli relations deteriorated during the late 2000s. First, Israel's Operation 'Cast Lead' against Hamas-led Gaza in December 2008 and January 2009 was criticized heavily by then Prime Minister Erdoğan at the World Economic Forum in Davos (International Crisis Group, 2010: 3). The dispute was followed by the 'Mavi Marmara' incident in May 2010. The Mavi Marmara was part of an international flotilla that aimed to provide direct aid to Gaza despite the Israeli blockade of the area. Israel intercepted the flotilla in international waters and killed eight Turkish citizens and one US citizen of Turkish descent aboard the vessel (International Crisis Group, 2010: 4). In the aftermath, Turkey withdrew its ambassador from Israel and expelled Israel's ambassador from Turkey. In response, the EU regretted the loss of life and condemned the use of violence. It called for 'an immediate, full and impartial inquiry' that included 'credible international participation'. Moreover, by adding that ' $[\mathrm{t}] \mathrm{he}$ continued policy of closure [was] unacceptable and politically counterproductive' (Council of the EU, 2010: 11), the EU to some extent also supported Turkey's perspective.

To conclude, during the period 2003 to 2010 , despite limited divergences, Turkey's prevailing ethos of the period-relying on soft power and cooperating with neighbors - was generally in line with the EU's foreign policy approach. In addition, Turkey's alignment with the CFSP 
declarations of the EU was consistently high throughout this period, showing Turkey's political will to harmonize its foreign policy with that of the EU. Ankara aligned itself with 45 out of 46 CFSP declarations of the EU in 2007 (European Commission, 2007: 74). During 2008 to 2010, Turkey continued its broad compatibility with CFSP, aligning itself with 109 of a total of 124 CFSP declarations in 2008, with 99 CFSP declarations out of 128 in 2009, and with 54 out of 73 of the relevant EU declarations and Council decisions in 2010 (European Commission, 2008: 83, 2009: 87, 2010: 95). This high convergence between foreign policies led pundits to call for advanced cooperation between the EU and Turkey in the Balkans and the Middle East (Grabbe \& Ülgen, 2010; Barysch, 2010).

All in all, this period can be seen as the 'golden age' of the compatibility of Turkey's foreign policy with that of the EU. In contrast to the 1990s, Turkey's regional engagement seemed to be producing results, as it was seen as a role model for its neighbors. Turkey's above-mentioned foreign policy divergences from its traditional allies, regarding Hamas, Iran, and Israel, were no doubt facilitated by the government's desire to leave an imprint in the international arena. During this period Turkey engaged with its regional neighbors to an unprecedented level and aimed to rise as a regional power through the use of soft power. In the words of Yorulmazlar and Turhan (2015: 337), Turkey took on a role of 'a strategic interconnector between regional interlocutors, as well as between the West and the Middle East'. However, the picture started to change after the Arab uprisings of 2010 and 2011.

\subsection{Diverging Paths in the Foreign Policies of TURKey AND THE EU: 2OII-2020}

\subsubsection{The Arab Spring and the War in Syria}

Changing dynamics in the Middle East in 2010 and 2011 left Turkey in a situation where the AKP's policy of zero-problems with neighbors was no longer sustainable. During this period, Turkey's foreign policy toward its neighbors focused on interventionism, and it risked being associated with certain factions in neighboring countries, to the extent that its foreign policy became largely incompatible with that of the EU.

When President Mohammed Morsi of Egypt was toppled by a military coup on July 3, 2013, Prime Minister Erdoğan condemned the coup. 
He criticized Morsi's trial vehemently, to which Egypt's new administration responded by expelling the Turkish ambassador from Cairo and downgrading its diplomatic relations with Turkey. Turkey reciprocated by declaring the Egyptian ambassador persona non grata (Deeb, 2013). The EU did not respond to the military intervention in Egypt as vehemently as Turkey. It declared that 'the military must accept and respect the constitutional authority of the civilian power as a basic principle of democratic governance', but refrained from asking for President Morsi to be reinstalled. Instead, it stressed 'the importance of holding democratic elections in the shortest possible time' (Council of the EU, 2013: 1). It is notable that Turkey did not align itself with this declaration (Council of the EU, 2013: 2). Brussels also refrained from defining the event as a coup, instead defining it as an 'ousting' (European Commission, 2014: 2). After the presidential elections, which brought the leader of the military coup to presidency, the EU expressed 'its willingness to work closely with the new authorities in Egypt' and congratulated 'Abdel Fattah El-Sissi, as the new President of Egypt' (Council of the EU, 2014: 1).

In Syria, the Turkish government did not turn against Syrian President Bashar al-Assad immediately after the uprisings began (Davutoğlu, 2013: 869). The delay in this case was mainly due to the personal efforts of Erdoğan and Davutoğlu, who first attempted to convince Assad to support reforms. Turkey's economic cooperation with Syria was also a source of concern that delayed support for regime change. As Assad chose to suppress the protests in his country, Turkey made a 180-degree turn on its Syria policy. It aimed to overthrow the Assad regime, and began hosting the oppositional Free Syrian Army and Syrian National Council in 2011 (Stackoct, 2011). The AKP government was seen to have adopted a pro-Sunni sectarian foreign policy after the Arab Spring, as it supported Muslim Brotherhood or actors affiliated with Muslim Brotherhood against the existing regimes in the Middle East (Öniş, 2011: 3; Özkan, 2014: 134; Hatipoğlu \& Palmer, 2016: 245).

In what followed, Turkey's response to the developments in Syria increased its divergence from the EU. Both Turkey and the EU continued to share the belief that Assad had to resign (Council of the EU, 2016, 2017). However, Turkey's call for the establishment of a no-fly zone (BBC News, 2015) did not find support in the EU. In response to a request to establish a no-fly zone in Syria, then High Representative of the Union Federica Mogherini stated that refugees now living in Turkey would continue to run away rather than go back to Syria. In addition, she 
stated that safe zones could only be secured by a substantial ground presence in northern Syria, and she was not sure whether this was a realistic option (Weymouth, 2015).

The Syrian war influenced Turkey in a variety of ways, one of which was the constant flow of Syrian refugees into Turkey. By May 2020, Turkey was hosting 3.6 million Syrian refugees (UNHCR, 2020: 1). As Syrians arriving in Turkey tried to reach Europe irregularly, in particular in 2015, a humanitarian catastrophe unfolded, which exerted substantial pressure on EU member states to act. The EU had to negotiate with Turkey in order to secure its cooperation for tight border controls (Kingsley \& Rankin, 2016). The resulting EU-Turkey refugee 'deal' on Syrian refugees (European Council, 2016) was based on the return of irregular migrants who landed in Greece after 20 March 2016 and the resettlement of one Syrian refugee from Turkey to the EU for each Syrian returned from Greece to Turkey. The agreement also stipulated Ankara taking necessary measures to prevent irregular migration through Turkey, and the EU providing EUR 6 billion toward the Refugee Facility for Turkey (Reiners \& Tekin, 2020: 119). Notwithstanding subsequent problems with the functioning of the arrangement, it does indicate that despite the remaining divergences between the EU and Turkey, there is potential for interest-driven, issue-specific cooperation in their foreign policies (Dimitriadi et al., 2018; Saatçioğlu et al., 2019: 5; Saatçioğlu, 2020: 171). In Syria, when the Democratic Union Party (Partiya Yekitiya Demokrat, PYD) established self-governing cantons in the north in 2013, Turkish policymakers feared the creation of another autonomous Kurdish region on Turkey's frontiers. For Turkey, the PYD and its armed unit, the People's Protection Units (YPG), are identical to the Kurdistan Workers' Party (Partiya Karkerên Kurdistanê, PKK), considered a terrorist organization with the aim of separating from Turkey. For Western actors, in particular the US and EU member states, the PYD was a useful partner in the fight against the terrorist group known as 'Islamic State' (IS). This difference and Turkey's initial refusal to take part in the anti-IS coalition until 2015 increased the distance between the EU and Turkey (Park, 2015: 585-586).

In August 2016 and January 2018, Turkey launched two military operations in northern Syria (Operation Euphrates Shield and Operation Olive Branch) with the objective of cleansing areas close to the border with Turkey of terrorists, including the PYD/YPG and IS (Kasapoğlu, 2017; Hürriyet Daily News, 2018). Concerning Operation Euphrates Shield, 
former EU High Representative Javier Solana (2017) stated, 'the US and the EU are concerned about Turkey's attacks against the PYD, given its central role in pushing back the Islamic State'. Similarly, regarding Operation Olive Branch, the EU High Representative at the time, Federica Mogherini, voiced doubts in 2018 about the effectiveness of the operation in terms of achieving peace in Syria and stated that 'we believe that all military action should focus on UN-listed terrorist organizations, not others; and it should not make peace harder to achieve' (EEAS, 2018). In February 2020, military attacks by the Syrian regime killed 33 Turkish soldiers in Idlib and Turkey launched another military operation (Operation Peace Spring) (BBC News, 2020). Tension decreased as Turkey and Russia agreed on a ceasefire and on monitoring the region together (Aljazeera, 2020).

During the Idlib crisis in February 2020, Turkey let refugees cross its borders with Greece in an effort to draw attention to Idlib, to obtain stronger EU support for refugees in its territory, and to force Russia into an agreement on a ceasefire (Harris, 2020). Turkey's move amounted to a violation of the EU-Turkey refugee 'deal', intended to avoid a migration crisis at Europe's borders. In addition to being motivated by the Idlib crisis, the move reflected Turkey's grievances about the EU's insufficient financial support for the refugees Turkey hosted and the EU's unmet promises to update the EU-Turkey Customs Union, revive the accession negotiations, and initiate visa-free travel for Turkish citizens (Cook, 2020). Reportedly, the EU ambassadors were outraged by 'what they see as an attempt by Turkish President Tayyip Erdogan to 'blackmail' the bloc by allowing migrants to mass at Greece's border' (Baczynska \& Chalmers, 2020). In order to reach a solution, European Council President Charles Michel and Commission President Ursula von der Leyen met with President Erdoğan. However, they have only been able to agree to task the High Representative of the EU, Josep Borrell, and the Turkish foreign minister, Mevlüt Çavuşoğlu with identifying EU-Turkish differences and challenges regarding the implementation of the 2016 refugee 'deal' (Herszenhorn \& Barigazzi, 2020).

\subsubsection{Cyprus and the Eastern Mediterranean}

Turkey and the EU have also clashed over the Greek Cypriot and Turkish drilling activities in the Eastern Mediterranean. Unlike previous differences between the EU and Turkey over Cyprus, the issue is not a foreign 
policy matter for the EU, as Cyprus has been a member of the institution since 2004. However, Turkey's approach toward the gas drilling activities of Cyprus and its partners in the Eastern Mediterranean (Egypt, Greece, Israel) remains within the realm of its foreign policy. The issue shows that Turkey has moved further away from the EU's above-mentioned 'good neighborly relations' principle in foreign policy.

The waters of the Eastern Mediterranean really started to simmer when, on 8 February 2018, the Italian company Eni and the French company Total announced a breakthrough gas discovery at the Calypso block off the Cypriot coast, estimated to be comparable as size to the giant Zohr field (Andrei, 2018). However, Turkey tried to prevent the Greek Cypriot government from drilling in the area. A drillship chartered by ENI was stopped by the Turkish navy on 9 February 2018 (Maltezou, 2018). Turkey issued a statement criticizing the Greek Cypriot administration's activities, which disregarded the rights of Turkish Cypriots (Republic of Turkey Ministry of Foreign Affairs, 2018). The European Council described the actions of Turkey as 'illegal' and 'strongly' condemned them. Additionally, the Heads of State or Government called Turkey 'to cease these actions and respect the sovereign rights of Cyprus to explore and exploit its natural resources in accordance with EU and International Law' (European Council, 2018: 5). When Turkey started its own drilling activities in the Eastern Mediterranean in June 2019, the European Council called on Turkey 'to show restraint, respect the sovereign rights of Cyprus and refrain from any such actions' (European Council, 2019a: 4). Since Turkey did not stop its gas drilling activities, the Council of the EU decided to suspend negotiations on the Comprehensive Air Transport Agreement. The Council also agreed to reduce the pre-accession assistance to Turkey for 2020 and called on the European Investment Bank to review its lending activities in Turkey. Moreover, the Council agreed not to hold any further meetings of the Association Council and the EU-Turkey high level dialogues for the time being (Council of the EU, 2019). Suspension of the high level dialogue meetings means that one of the key instruments for facilitating EU-Turkey relations in the fields of energy, economy, transport, fight against terrorism, and particularly foreign policy would not be available in the foreseeable future (see also Bürgin, Chapter 9; Lippert, Chapter 11; Akman \& Çekin, Chapter 12).

Regardless of the EU's position on the issue, Turkey signed a Memorandum of Understanding on the delimitation of maritime jurisdictions in 
the Mediterranean Sea with the Government of National Accord of Libya in November 2019. Through this Memorandum, Turkey declared an extension of the Turkish Exclusive Economic Zone into the southeast of the island of Crete and claimed that regional actors had to 'negotiate with Turkey for any pipeline project to carry Eastern Mediterranean natural gas to European markets' (Daily Sabah, 2019). Thus, Turkey tried to obstruct the plans of Cyprus, Egypt, Greece, and Israel for transferring Eastern Mediterranean gas to Europe via a scheme that does not involve Turkish Cypriots and Turkey. In response, the European Council declared that the Turkey-Libya Memorandum of Understanding 'infringes upon the sovereign rights of third States, does not comply with the Law of the Sea and cannot produce any legal consequences for third States' (European Council, 2019b: 4). On this issue, the EU has continued to express solidarity with its member state Cyprus (Council of the EU, 2020).

Turkey's increasing divergence from the EU foreign policy after the Arab Spring can also be seen in its degree of alignment with the EU's CFSP declarations from 2011 onwards. Turkey aligned itself with only 32 out of the 67 relevant EU declarations and Council decisions in 2011 (48\% alignment) (European Commission, 2011: 106). In 2012, the rate of alignment slightly increased to 37 out of 70 (53\% alignment) (European Commission, 2012: 87) but was below 50\% between 2013 and 2016. In 2018, the rate of alignment reached an all-time low, when Turkey aligned itself with only 10 out of 64 EU declarations and Council decisions (around 16\% alignment) (European Commission, 2018: 96), and this trend continued in the following year with an alignment rate of around 18\% (European Commission, 2019: 99).

\subsection{CONCLUSION}

In 2018, the Council of the EU noted that 'Turkey has been moving further away from the European Union', and declared that Turkey's accession negotiations and the process of the modernization of the EUTurkey Customs Union came to a standstill (Council of the EU, 2018: 13). In such an atmosphere, foreign policy becomes even more important as an area where both parties have shared interests in preserving peace and stability in the EU's immediate neighborhood. Collaboration in foreign policy could provide a modicum of communication between parties with increasingly diverging normative perceptions and interests. 
However, as Turkey's foreign policy has gradually become less compatible with that of the EU, it seems that areas of future cooperation will be limited to issues where interests overlap, such as pandemics, counterterrorism, migration, and energy. And, as institutional connections and channels have been reduced, cooperation is likely to take place more through ad hoc mechanisms.

Despite the increasing divergence, it is obvious that pressing issues on the foreign policy agenda, such as the COVID-19 pandemic, migration, counterterrorism, and energy require the collaboration of the EU and Turkey. With regard to the COVID-19 pandemic, Turkey attended the international Coronavirus Global Response conference hosted by the European Commission in May 2020, and pledged to contribute to the financial pool for diagnostics, treatment, and vaccines. Turkey sent medical aid to Italy and Spain, which were hit hard by the virus, and the Joint Research Center of the EU has been making results and equipment available to Turkey (Aslan, 2020). Another area that may lead to cooperation in the future may be the Iranian dossier. ${ }^{3}$ In May 2018, former President Donald Trump withdrew the United States from the agreement on the Iranian nuclear program, reached in 2015, and announced that the US would impose sanctions on Iran in order to prevent Iranian nuclear ambitions (Landler, 2018). Both the EU and Turkey were in favor of adhering to the agreement, and were opposed to sanctions. Although the situation did not lead to joint action by the EU and Turkey so far, there is potential for cooperation on the basis of compatible positions and interests - also in view of the new US administration under President Biden.

The prospect of cooperation may increase if the EU develops an institutional framework that provides the possibility of joint actions with candidate countries in foreign policy issues. Alternatively, if Turkey and the EU agree on a relationship format short of membership, ${ }^{4}$ we may see extended cooperation between the EU and Turkey. In such a setup, Turkey's failure to meet the EU's political standards, in particular regarding democracy and the rule of law, would probably cease to be important and the relations could become de-politicized and more technical. However, limiting EU-Turkey relations to cooperation on specific

\footnotetext{
${ }^{3}$ I am grateful to Tuba Ünlü Bilgiç for bringing this to my attention.

${ }^{4}$ I am grateful to Atila Eralp for this idea.
} 
matters where interests overlap risks limiting the bilateral dialogue to a transactional format, which does not help Turkey's reform process as much as an accession-negotiations framework would.

\section{REFERENCES}

Akman, M. S., \& Çekin, S. E. (2021). The EU as an anchor for Turkey's macroeconomic and trade policy. Chapter 12 , in this volume.

Aljazeera (2020, March 12). Turkey says Idlib ceasefive details largely agreed on with Russia. https://www.aljazeera.com/news/2020/03/turkey-idlib-cea sefire-details-largely-agreed-russia-200312110120296.html. Accessed 12 May 2020.

Altunışı, M., \& Çuhadar, E. (2010). Turkey's search for a third party role in Arab-Israeli conflicts: A neutral facilitator or a principal power mediator? Mediterranean Politics, 15(3), 371-392.

Andrei, R. (2018, August 20). The Cyprus issue and natural gas in the Eastern Mediterranean. Geopolitical Monitor. https://www.geopoliticalmonitor.com/ the-cyprus-issue-and-natural-gas-in-the-eastern-mediterranean/. Accessed 9 Nov 2020.

Aslan, D. (2020, May 11). EU grateful for Turkey's solidarity, calls for unity amid COVID-19 pandemic: Envoy Berger. Daily Sabah. https://www.dailys abah.com/politics/eu-affairs/eu-grateful-for-turkeys-solidarity-calls-for-unityamid-covid-19-pandemic-envoy-berger. Accessed 13 May 2020.

Baczynska, G., \& Chalmers, J. (2020, March 3). Exclusive: EU fumes at Turk migration 'blackmail', mulls more money for Ankara. Reuters. https:// www.reuters.com/article/us-syria-security-eu-turkey-exclusive/exclusive-eufumes-at-turk-migration-blackmail-mulls-more-money-for-ankara-idUSKB N20Q2EK. Accessed 12 May 2020.

Barysch, K. (2010, December). Turkey and the EU: Can the stalemate be avoided? Policy Brief, Center for European Reform. https://www.cer.eu/publications/ archive/policy-brief/2010/turkey-and-eu-can-stalemate-be-avoided. Accessed 21 Nov 2020.

BBC News. (2015, August 11). Turkey PM: Syria no-fly zone needed. https:// www.bbc.com/news/world-europe-33868627. Accessed 10 Nov 2020.

BBC News. (2020, February 28). Syria war: Alarm after 33 Turkish soldiers killed in attack in Idlib. https://www.bbc.com/news/world-middle-east-516 67717. Accessed 12 May 2020.

Blua, A. (2010, May 17). Iran agrees to nuclear swap deal through Turkey. RFE/RL. https://www.rferl.org/a/Iran_Agrees_To_Nuclear_Swap_ Deal_Through_Turkey/2044249.html. Accessed 10 Nov 2020.

Bürgin, A. (2021). The European Commission's role in EU-Turkey relations. Chapter 9 , in this volume. 
Cook, L. (2020, March 06). EU, Turkey trade blame on deal as thousands gather at border. The Associated Press. https://apnews.com/7b76a6dba2547b622b 301d70ab3869ac. Accessed 3 Jul 2020.

Council of the European Union. (2010, June 14). 3023rd Council meeting Foreign Affairs. Press release. 11022/10. Luxembourg.

Council of the European Union. (2013, July 14). Declaration by the High Representative Catherine Ashton, on behalf of the European Union, on the situation in Egypt. 12306/1/13 REV 1. Brussels.

Council of the European Union. (2014, June 5). Declaration on behalf of the European Union on the presidential elections in Egypt. 10649/1/14 REV 1. Brussels.

Council of the European Union. (2016, October 17). Council conclusions on Syria. 13193/16. Luxembourg.

Council of the European Union. (2017, April 3). Council Adopts EU strategy on Syria. Press release. 180/17. Brussels.

Council of the European Union. (2018, June 26). Enlargement and stabilisation and association process, Council conclusions. 10555/18. Brussels.

Council of the European Union (2019, July 15). Turkish drilling activities in the Eastern Mediterranean: Council adopts conclusions. Press Release. https:// www.consilium.europa.eu/en/press/press-releases/2019/07/15/turkishdrilling-activities-in-the-eastern-mediterranean-council-adopts-conclusions/. Accessed 27 Nov 2020.

Council of the European Union. (2020, April 23). Conclusions of the president of the European Council following the video conference of the members of the European Council. https://www.consilium.europa.eu/en/press/press-rel eases $/ 2020 / 04 / 23 /$ conclusions-by-president-charles-michel-following-thevideo-conference-with-members-of-the-european-council-on-23-april-2020/. Accessed 29 Jul 2020.

Daily Sabah. (2017, May 3). Give peace, and reforming Hamas a chance. https://www.dailysabah.com/editorial/2017/05/03/give-peace-and-reform ing-hamas-a-chance. Accessed 10 Nov 2020.

Daily Sabah. (2019, November 28). Maritime deal with Libya secures Turkey's rights in Mediterranean. https://www.dailysabah.com/diplomacy/2019/11/ 28/turkey-libya-sign-cooperation-maritime-jurisdiction-agreements. Accessed 13 May 2020.

Davutoğlu, A. (2001). Stratejik derinlik (6th ed.). Istanbul: Küre Yayınları.

Davutoğlu, A. (2013). Turkey's humanitarian diplomacy: Objectives, challenges and prospects. Nationalities Papers: the Journal of Nationalism and Ethnicity, $41(6), 865-870$.

Deeb, S. E. (2013, November 23) What's behind Egypt vs. Turkey diplomatic feud? The Christian Science Monitor. https://www.csmonitor.com/World/ 2013/1123/What-s-behind-Egypt-vs.-Turkey-diplomatic-feud. Accessed 10 Nov 2020. 
Dimitriadi, A., Kaya, A., Kale, B., \& Zurabishvili, T. (2018, March). EU-Turkey relations and irregular migration: Transactional cooperation in the making. FEUTURE Online Paper No.16. https://feuture.uni-koeln.de/sites/feu ture/user_upload/FEUTURE_Online_Paper_No_16_D6.3.pdf. Accessed 15 May 2020.

Dinçer, O. B., \& Kutlay, M. (2013). The Arab Spring: A game changer in Turkey-EU relations? Perspectives on European Politics and Society, 14(4), $418-430$.

Emerson, M., \& Tocci, N. (2004, August). Turkey as a bridgehead and spearhead: Integrating EU and Turkish foreign policy. EU-Turkey Working Papers No. 1, Center for European Policy Studies. http://aei.pitt.edu/6765/1/1143_01. pdf. Accessed 27 Nov 2020.

Eralp, A. (2010). Conclusion: Diverging or converging orientations in the neighbourhood. In A. Eralp \& C.. Üstün (Eds.), Turkey and the EU: The process of change and neighbourhood (pp. 207-221). Ankara: Zeplin İletişim.

European Commission. (1998, December 17). Regular report from the Commission on Turkey's progress towards accession. $\operatorname{COM}(98) 711$ final.

European Commission. (1999, October 13). 1999 Regular report from the Commission on Turkey's progress towards accession. $\mathrm{COM}(99) 0513$ final.

European Commission. (2000, October 8). 2000 Regular report from the Commission on Turkey's progress towards accession. $\operatorname{COM}(2000) 713$ final.

European Commission. (2001, November 13). 2001 Regular report on Turkey's progress towards accession. SEC(2001) 1756. Brussels.

European Commission. (2002, October 9). 2002 Regular report on Turkey's progress towards accession. SEC(2002) 1412. Brussels.

European Commission. (2003, November 5). 2003 Regular report on Turkey's progress towards accession. $\operatorname{COM}(2003) 676$ final. Brussels.

European Commission. (2004, October 6). 2004 Regular report on Turkey's progress towards accession. SEC(2004) 1201. Brussels.

European Commission. (2007, November 6). Turkey 2007 progress report. SEC(2007) 1436. Brussels.

European Commission. (2008, November 5). Turkey 2008 progress report. $\operatorname{SEC}(2008)$ 2699. Brussels.

European Commission. (2009, October 14). Turkey 2009 progress report. SEC(2009)1334. Brussels.

European Commission. (2010, November 09). Turkey 2010 progress report, SEC(2010) 1327. Brussels.

European Commission. (2011, October 12). Turkey 2011 progress report. $\operatorname{COM}(2011)$ 666. Brussels.

European Commission. (2012, October 10). Turkey 2012 progress report. $\operatorname{SWD}(2012) 336$ final. Brussels. 
European Commission. (2014, March 27). Implementation of the European neighbourhood policy in Egypt: Progress in 2013 and recommendations for action. SWD(2014) 71 final. Brussels.

European Commission. (2018, April 17). Turkey 2018 report. SWD(2018) 153 final. Strasbourg.

European Commission. (2019, May 29). Turkey 2019 report. SWD(2019) 220 final. Brussels.

European Council. (1988). European Counil Rhodes (2 and 3 December 1988)Conclusions of the presidency. SN 4443/1/88. https://www.consilium.europa. eu/media/20597/1988_december_-_rhodes_eng_.pdf. Accessed 29 Nov 2020.

European Council. (1992, December 12). European Council in Edinburgh (11 and 12 December 1992)-Conclusions of the Presidency. Declaration on the former Yugoslavia, conclusions of the presidency. Annex D.1. SN 456/1/92 REV 1. Edinburgh.

European Council. (2016, March 18). EU-Turkey statement. Press Release. https://www.consilium.europa.eu/en/press/press-releases/2016/03/18/ eu-turkey-statement/. Accessed 27 Nov 2020.

European Council. (2018, March 23). European Council meeting (22 March 2018)_Conclusions. EUCO 1/18. Brussels.

European Council. (2019a, June 20). European Council meeting (20 June 2019)-Conclusions. EUCO 9/19. Brussels.

European Council. (2019b, December 12). European Council meeting (12 December 2019)_Conclusions. EUCO 29/19. Brussels.

European External Action Service. (2018, February 6). Speech by High Representative/Vice-President Federica Mogherini at the European Parliament plenary session on the human rights situation in Turkey and the situation in Afrin, Syria. ID 180207_5. Brussels.

European Political Cooperation. (1973). Declaration of the nine foreign ministers of November 6, 1973 in Brussels on the Situation in the Middle East. https:// www.cvce.eu/obj/joint_statement_by_the_governments_of_the_eec_6_nove mber_1973-en-a08b36bc-6d29-475c-aadb-0f71c59dbc3e.html. Accessed 27 Nov 2020.

European Political Cooperation. (1974, July 16). Communiqué by the nine governments on the situation in Cyprus. http://aei.pitt.edu/5575/1/5575. pdf. Accessed 27 Nov 2020.

European Political Cooperation. (1980, January). The Community's reactions to the invasion of Afghanistan. http://aei.pitt.edu/5582/1/5582.pdf. Accessed 2 Aug 2020.

European Political Cooperation. (1982, April 25). Statement on the Israeli bombing of Lebanon. http://aei.pitt.edu/5584/1/5584.pdf. Accessed 2 Aug 2020. 
Evin, A., \& Hatipoğlu, E. (2014). Convergence or divergence: EU and Turkish foreign policy over the last decade. In P. Balazs (Ed.), A European Union with 36 Members? Perspectives and Risks (pp. 185-198). Budapest: Central European University Press.

Fırat, M., \& Kürkçüoğlu, Ö. (2008). Ortadoğu'yla ilişkiler. In B. Oran (Ed.), Türk dış politikası 1980-2001 (pp. 124-149). Istanbul: İletişim.

Grabbe, H., \& Ülgen, S. (2010, December). The way forward for Turkey and the EU: A strategic dialogue on foreign policy. Policy Outlook, Carnegie Endowment for International Peace. https://carnegieendowment.org/files/turkey_ eu_policyl.pdf. Accessed 27 Nov 2020.

Hale, W. (2000). Turkish Foreign Policy 1774-2000. London: Frank Cass.

Harris, C. (2020, March 4). Europe's migrant crisis: Why Turkey let refugees head for EU and the link with Syria. Euronews. https://www.euronews. $\mathrm{com} / 2020 / 03 / 03 /$ europe-s-migrant-crisis-why-turkey-let-refugees-head-foreu-and-the-link-with-syria. Accessed 12 May 2020.

Hatipoğlu, E., \& Palmer, G. (2016). Contextualizing change in Turkish foreign policy: The promise of the 'two-good' theory. Cambridge Review of International Affairs, 29(1), 231-250.

Herszenhorn D. M., \& Barigazzi, J. (2020, March 9). EU leaders meet Erdoğan to resolve fight over refugees. Politico. https://www.politico.eu/article/erd ogan-meeting-brussels-eu-leaders-refugees-fight/. Accessed 12 May 2020.

Hill, C. (2016). Foreign policy in the twenty-first century (2nd ed.). London: Palgrave Macmillan.

Hürriyet Daily News. (2018, January 20). Turkey launches 'olive branch operation' against 'PKK threat in Syria'. http://www.hurriyetdailynews.com/tur key-launches-major-land-operation-into-ypg-militants-in-syrias-afrin-126031. Accessed 10 Nov 2020.

International Crisis Group. (2010). Turkey's crises over Israel and Iran. Report No. 208. 8 September.

Kasapoğlu, C. (2017, February 3). Operation Euphrates shield: Progress and scope. Aljazeera. https://www.aljazeera.com/opinions/2017/2/3/ope ration-euphrates-shield-progress-and-scope/. Accessed 27 Nov 2020.

Kaya, A. (2021). Europeanization and de-Europeanization of Turkish asylum and migration policies. Chapter 14, in this volume.

Kingsley, P., \& Rankin, J. (2016, March 8). EU-Turkey refugee deal-Q\&A. The Guardian. https://www.theguardian.com/world/2016/mar/08/eu-tur key-refugee-deal-qa. Accessed 10 Nov 2020.

Kirişci, K. (2018). Turkey and the West: Fault lines in a troubled alliance. Washington: The Brookings Institution.

Krieger, H. L. (2006, February 16). Livni slams Turkey for receiving Hamas. The Jerusalem Post. https://www.jpost.com/Israel/Livni-slams-Turkey-for-receiv ing-Hamas. Accessed 21 Nov 2020. 
Landler, M. (2018, May 8). Trump abandons Iran nuclear deal he long scorned. The New York Times. https://www.nytimes.com/2018/05/08/world/mid dleeast/trump-iran-nuclear-deal.html. Accessed 10 Nov 2020.

Lippert, B. (2021). Turkey as a special and (almost) dead case of EU enlargement policy. Chapter 11, in this volume.

Maltezou, R. (2018, February 23). Cyprus accuses Turkey of blocking ship again in gas exploration standoff. Reuters. https://www.reuters.com/article/ us-cyprus-natgas-turkey/cyprus-accuses-turkey-of-blocking-ship-again-in-gasexploration-standoff-idUSKCNlG71MF. Accessed 21 Nov 2018.

Milliyet. (1997, December 11). Demirel İKÖ Zirvesini terkedip döndü.

Nye, J. S. (1990). Soft power. Foreign Policy, 80(1990), 153-171.

Oxford English Dictionary. (2020). Entry on 'compatibility'. https://www. oed.com/view/Entry/37498? redirectedFrom=compatibility\#eid. Accessed 30 June 2020.

Öniş, Z. (2011). Multiple faces of the 'new' Turkish foreign policy: Underlying dynamics and a critique. Insight Turkey, 13(1), 47-65.

Özkan, B. (2014). Turkey, Davutoglu and the idea of pan-Islamism. Survival, $56(4), 119-140$.

Park, B. (2015). Turkey's isolated stance: An ally no more, or just the usual turbulence? International Affairs, 91(3), 581-600.

Reiners, W., \& Tekin, F. (2020). Taking refuge in leadership? Facilitators and constraints of Germany's influence in EU migration policy and EU-Turkey affairs during the refugee crisis (2015-2016). German Politics, 29(1), 115130.

Republic of Turkey Ministry of Foreign Affairs. (2018, February 11). GKRY'nin Doğu Akdeniz'deki Hidrokarbon Faaliyetleri Hk. http://www.mfa.gov. tr/no_-43_-gkrynin-dogu-akdenizdeki-hidrokarbon-faaliyetleri-hk.tr.mfa. Accessed 10 Nov 2020.

Republic of Turkey Ministry of Foreign Affairs. (2020). Turkey's political relations with the state of Palestine. http://www.mfa.gov.tr/turkey_s-political-relationswith-the-palestinian-national-authority.en.mfa. Accessed 10 Nov 2020.

Saatçioğlu, B. (2020). The European Union's refugee crisis and rising functionalism in EU-Turkey relations. Turkish Studies, 21(2), 169-187.

Saatçioğlu, B., Tekin, F., Ekim, S., \& Tocci, N. (2019, March). The Future of EU-Turkey relations: A dynamic association framework amidst conflictual cooperation. FEUTURE Synthesis Paper. https://feuture.uni-koeln.de/sites/mon teus/user_upload/FEUTURE_Synthesis_Paper.pdf. Accessed 27 Nov 2020.

Solana, J. (2017, March 23). Turkey's alarming turn with Erdoğan. What the EU needs to do? Euronews. http://www.euronews.com/2017/03/23/view-tur keys-alarming-turn-with-erdogan-what-the-eu-needs-to-do. Accessed $10 \mathrm{Nov}$ 2020. 
Sözen, A. (2010). A paradigm shift in Turkish foreign policy: Transition and challenges. Turkish Studies, 11(1), 103-123.

Sözen, A. (2013). Turkey's new Cyprus policy: Transforming a military base into a basin of cooperation. In E. Canan Sokullu (Ed.), Debating security in Turkey: Challenges and changes in the twenty-first century (pp. 109-122). Plymouth: Lexington Books.

Stackoct, L. (2011, October 27). In slap at Syria, Turkey shelters antiAssad fighters. The New York Times. http://www.nytimes.com/2011/10/ 28/world/europe/turkey-is-sheltering-antigovernment-syrian-militia.html. Accessed 10 Nov 2020.

Tellal, E. (2008). SSCB'yle ilişkiler. In B. Oran (Ed.), Türk dış politikası 19191980 (pp. 769-783). Istanbul: İletişim.

Torun, Z. (2016). The debate on 'Turkey as a role model'. Avrasya Etüdleri, 22(49), 7-32.

UNHCR, The UN Refugee Agency. (2020, May). Operational update. http:// reporting.unhcr.org/sites/default/files/UNHCR\%20Turkey\%20Operati onal\%20Update\%20-\%20May\%202020.pdf. Accessed 30 Jun 2020.

Ünal Eriş, Ö. (2007). The European neighbourhood policy and Turkey. In E. LaGro \& K. E. Jørgensen (Eds.), Turkey and the European Union: Prospects for a difficult encounter (pp. 203-220). New York: Palgrave Macmillan.

Üstün, Ç. (2010). EU and Turkish neighborhood policies: Common goals. Caucasian Review of International Affairs, Autumn, 4(4), 342-353.

Uzgel, İ. (2008). Balkanlarla ilişkiler. In B. Oran (Ed.), Türk dış politikası 19802001 (pp. 481-523). Istanbul: İletişim.

Weymouth, L. (2015, October 2). E.U. foreign policy chief: Here's what to do about the refugee crisis. The Washington Post. https://www.washingtonpost. com/opinions/eu-foreign-policy-chief-heres-what-to-do-about-the-refugeecrisis /2015/10/02/0af01782-67a4-11e5-9ef3-fde182507eac_story.html? utm_term=.87e711628c99. Accessed 10 Nov 2020.

Winrow, G. M. (2007). Turkey and the Greater Black Sea region. In N. A. Güney (Ed.), Contentious issues of security and the future of Turkey (pp. 121-136). Aldershot: Ashgate.

Yorulmazlar, E., \& Turhan, E. (2015). Turkish foreign policy towards the Arab Spring: Between Western orientation and regional disorder. Journal of Balkan and Near Eastern Studies, 17(3), 337-352.

Zerrin Torun is associate professor at the Department of International Relations at the Middle East Technical University (METU), Ankara. She holds a B.A. in International Relations from METU, an MA in European Politics and Policies from the University of Manchester and a Ph.D. from the University of Sussex. Her research interests include European foreign and security policy, Turkish foreign policy, critical security studies, and Europeanization. 
Open Access This chapter is licensed under the terms of the Creative Commons Attribution 4.0 International License (http://creativecommons.org/licenses/ by $/ 4.0 /$ ), which permits use, sharing, adaptation, distribution and reproduction in any medium or format, as long as you give appropriate credit to the original author(s) and the source, provide a link to the Creative Commons license and indicate if changes were made.

The images or other third party material in this chapter are included in the chapter's Creative Commons license, unless indicated otherwise in a credit line to the material. If material is not included in the chapter's Creative Commons license and your intended use is not permitted by statutory regulation or exceeds the permitted use, you will need to obtain permission directly from the copyright holder.

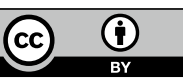

